\title{
Real Time Street Light Automation Using Arduino
}

\author{
Patil Piyush Prakash ${ }^{1 *}$, Digvijay Patil ${ }^{2}$, Rupesh Patil ${ }^{3}$, Vijay D. Chaudhari ${ }^{4}$, Dr. A. J. Patil ${ }^{5}$ \\ ${ }^{1,2,3}$ UG Student, ${ }^{4}$ Asstt. Prof. ${ }^{5}$ Professor \\ ${ }^{1,2,3,4}$ E\&TC Engg dept, GF'S Godavari College of Engineering, Jalgaon \\ ${ }^{5}$ Samarth Group's College of Engg. Belhe, Punn
}

Received on: 16 July,2021

Revised on: 21 August, 2021

Published on: 23 August, 2021

\begin{abstract}
Now-a-days the amount of power consumed by lighting and streets shares a major energy demand. The Street light Automation system helps in reducing the energy consumption. Generally, street lights are switched on for whole night and during the day, they are switched off. But during the night time, street lights are not necessary if there is no traffic. Saving of this energy is very important factor these days as energy resources are getting reduced day by day. To overcome from this problem, a proper energy saving methods and lighting control to be implemented. The proposed work is to have two controls like, one is to switch OFF/Dim lights during no vehicle moments in streets and automatically switch it $O N$ when vehicles arrive and the other modes are to give less intensity light for pedestrian and to switch on bright mode during vehicle moments at sides on the roads. In this work the LED lights are used for street arrangement, LDR is used as decide day night time and IR sensor used vehicle movement. It automatically switches the lights $O N$ when the sunlight goes below the visible region of our eyes. This is done by a sensor called Light Dependent Resistor (LDR) which senses the light actually like our eyes. It automatically switches OFF/ Dim lights whenever the sunlight comes visible to the sensor. The control signals of sensors have been fed to Arduino Nano board (ATMEGA328). In the Arduino Nano board the control logic is implemented to control lights based on vehicles and pedestrian moments with bright and dim mode of operation and to switch DIM lights during no vehicles.
\end{abstract}

Keywords - Light Dependent Resistor (LDR), Arduino ATMEGA328, Street Light Automation, RTC

\section{I - INTRODUCTION}

$\mathbf{F}$ orm olden days we're using non-renewable sources of energy in excess mount for our needs. As this type of minerals like coal etc. are exhausting so we have to depend on the renewable sources of energy like solar, wind, etc. For smaller application it is better to use renewable energy. As this project is based on streetlight automation and required AC supply. So for this particular application we are using solar panels to charge the DC battery and the power from the battery can be used for this application. Advertising hoardings, commercial sign boards, and street lights are generally switched on at 6:30 pm and switched off at 10:00 am because nobody is available at the place in the morning to switch it off. But actual required time is $6: 30 \mathrm{pm}$ to $11: 30 \mathrm{pm}$ and 4:30am to 6:30am. Meantime i.e., from $11: 30 \mathrm{pm}$ to $4: 30 \mathrm{am}$ is not required, because the public flow on the roads is almost nil in this time. And from 6:30am to 10:00am is also not required as the sun light is available during this time. That means every day around nine hours of power is wasted. This project gives the best solution for electrical energy wastage. Also the manual operation of the lighting system is completely eliminated. The Project ATMEGA328 Microcontroller Based Energy saver for Commercial Lighting system with RTC DS3231 Interfacing is an interesting project which uses ATMEGA328 microcontroller as its brain. This project is very useful for commercial sign boards, advertising boards, street lights for automation lighting system. This system switches on the lights only at preprogramed timings. As the DS3231 Real Time Clock chip with battery back-up is used, there will be no disturbances for the programmed on/off timings even in power failures. Control switch set is provided for entering 


\section{International Journal of Innovations in Engineering and Science, www.ijies.net}

the required timings. 4-digit seven segment display is provided to display the alarm times and current time. DS3231 is interfaced to the microcontroller for real timing performance. A $3 \mathrm{~V}$ battery can be connected to DS3231 to avoid time disturbances caused by power failures. ATMEGA328 has inbuilt flash EPROM. Data stored remains in the memory even after power failure, as the memory ensures reading of the latest saved settings by the micro controller. It can retain data for more than ten years.

\section{II- LITERATURE SURVEY}

The Energy efficient smart street light [1] analyzed the road light with auto tracking system by which one can increase the conversion efficiency of the solar power generation. Here, the sun tracking sensor is that the sensing device which senses the position of the sun time to time and provides the output to the amplifier supported light density of the sun [2]. That have proposed about Street Light Glow on detecting vehicle movement using sensor could even be a system that utilizes the foremost recent technology for sources of sunshine as LED lamps. it's also wont to control the switching of street light automatically consistent with the sunshine intensity [3][4].The implemented design of traffic flow based street light system with effective utilization of solar power within the year 2015. They used the renewable source of energy i.e. the solar energy for street lighting [5].He is surveyed on Street Lighting System supported Vehicle Movements. The system operates within the automatic mode which regulates the road light consistent with brightness and dimness [6]. To proposed a ZigBee based remote Automatic Street Light System. The system is meant with the assistance of ZigBee modules that helps in detecting the faulty lights and control the sunshine [7].The reports on the 2 installation case studied in Scotland and Wales and explain the small print and benefits of the technology. The system was called as MINOS that had a diary of over 100,000 units installed and dealing successfully[8].She is explains a system to scale back the facility consumption of street lights by avoiding inefficient lighting which wastes significant financial resources annually . this is often done by dimming the lights during less traffic hours [9].He has used an automatic microprocessor with photovoltaic cell [10].The street light optimizer [11].An Intelligent Street Lighting system for smart city supported IOT [12].The Automatic Street Light system using Wireless Sensor Networks [13]. From this literature survey, the methods all has implemented and used is simple and easy to understand. These papers are focused to further implement how efficient system and make things automated.

\subsection{Problem Statement}

Wastage of power from street lights is one of the power loss system. The vehicles are passing over always and part of places will be consisting of less density areas and even no vehicle movement itself in few areas. But during night all street lights will be on in conventional street lighting system.

\subsection{Proposed Method/System}

We proposed a way based on that Automatic Street Lighting System ON/OFF/DIM according to the timings like day time or night time, and at night time continuous track the movement of vehicle or objects,(by IR sensors) for Switching of Street Lights automatically. It uses a Sensor named LDR sensor, which is a light dependent variant; which means depends on light intensity and device called RTC which stands for Real Time Clock which provides the details such as day month year date and time according to which the street lights are made ON and OFF. To achieve more accuracy. And it designed around a microcontroller which forms the heart of the system, similarly; manual power reduces.

\section{III - METHODOLOGY}

\subsection{System Hardware}

Here the IR sensors is used to pass the object in front of sensor which is drive by ATMEGA328.

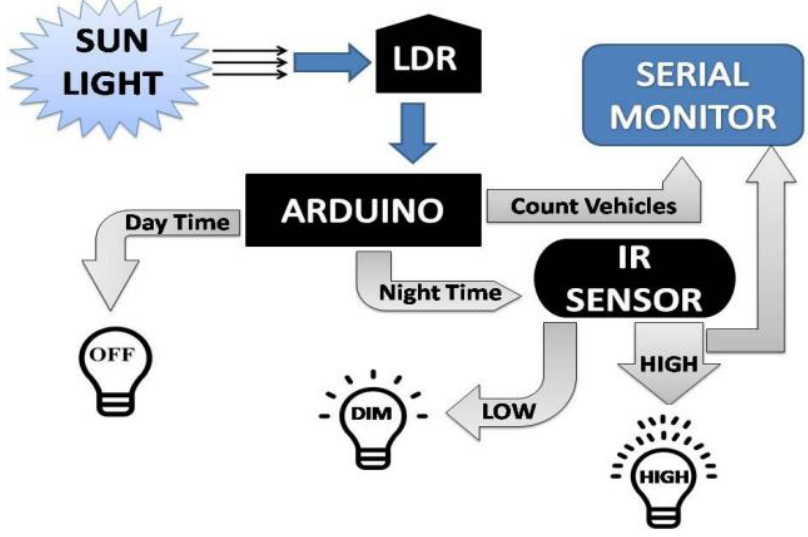

Fig 3.1-The architecture design of automatic street light control system

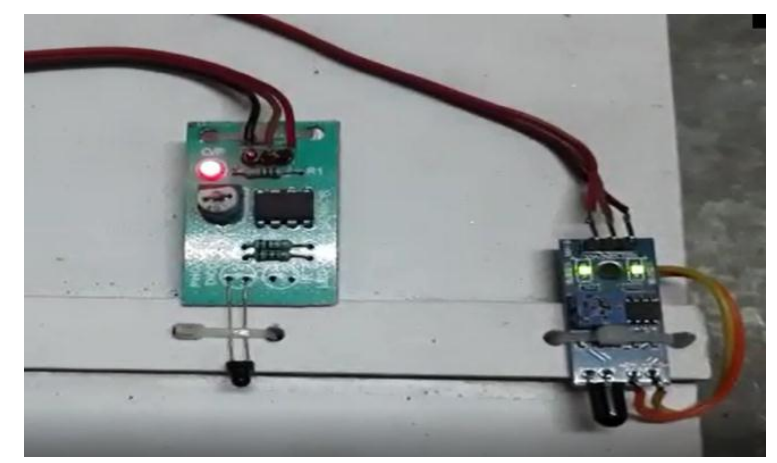

Fig 3.2- SYSTEM'S IR Sensors (Two Receiver) 


\section{International Journal of Innovations in Engineering and Science, www.ijies.net}

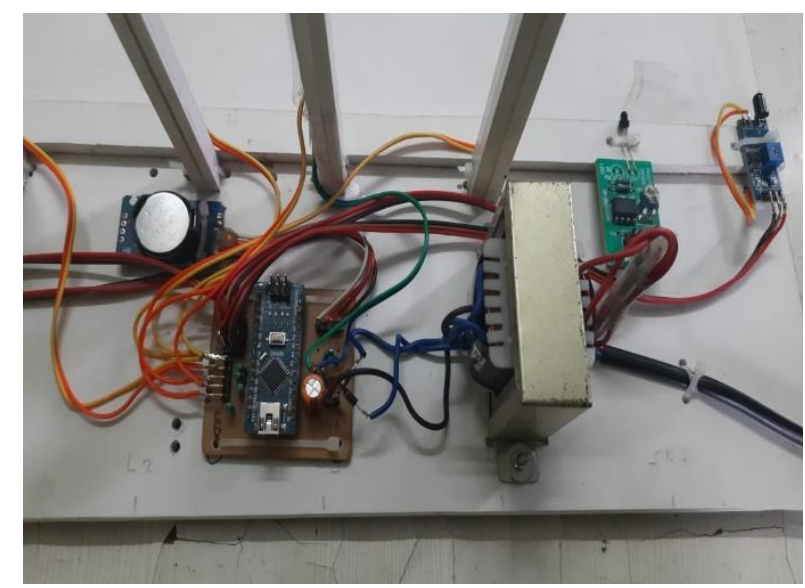

Fig 3.3-System Hardware ATMEGA328
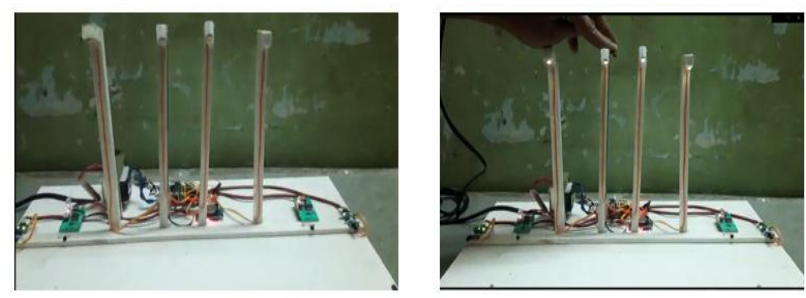

Figure 3.4.1-Light is OFF i.e. Day Condition Figure3.4.2-Light is DIM i.e. Night Condition
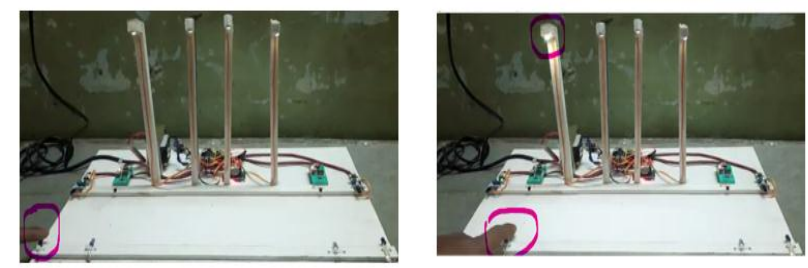

Figure 3.4.3- $1^{\text {st }}$ IR Sensor sense Vehicle and Microcontroller start Calculating Speed of the Vehicle

Figure 3.4.4-As soon As $2^{\text {nd }}$ IR Sensors Sense the Light glow brighter, before object is reach. As per speed of the vehicle.
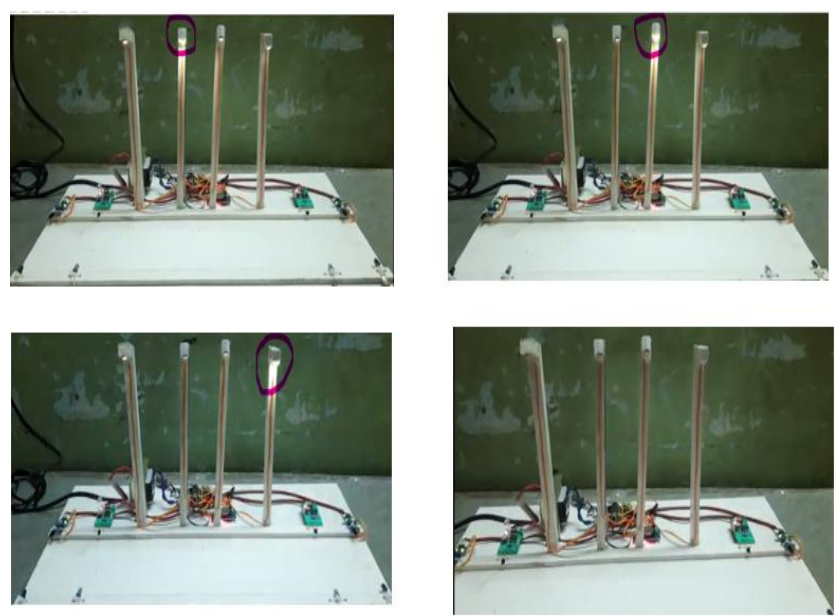

Fig 3.4.5-And Step by step Next Street Lamp start Glow Brighter as per calculated Speed of the vehicle/object that is detected by the Microcontroller, using IR sensor. And Street Light again goes into a DIM condition.
Table 1 - Derived results after implementation.

\begin{tabular}{|c|c|c|c|}
$\begin{array}{c}\text { Sr. } \\
\text { No. }\end{array}$ & Direction & $\begin{array}{c}\text { Time (micro } \\
\text { seconds) }\end{array}$ & $\begin{array}{c}\text { Speed } \\
\text { (mm=55/sec) }\end{array}$ \\
\hline 01 & Left to Right & 689 & 37.9 \\
\hline 02 & Left to Right & 1045 & 57.5 \\
\hline 03 & Left to Right & 2568 & 141.2 \\
\hline 04 & Right to left & 897 & 49.3 \\
\hline 05 & Right to left & 1423 & 78.3 \\
\hline 06 & Right to left & 2164 & 119.0 \\
\hline 07 & Both sides & $\begin{array}{c}\text { Left(2215) } \\
\text { Right(1986) }\end{array}$ & $\begin{array}{c}\text { Left(121.8) } \\
\text { Right (109.2) }\end{array}$ \\
\hline 08 & Both sides & $\begin{array}{c}\text { Left( }(963) \\
\text { Right(1846) }\end{array}$ & $\begin{array}{c}\text { Left(53.0) } \\
\text { Right(101.5) }\end{array}$ \\
& & & \\
\end{tabular}

In Table No 1 shows direction of the vehicle /object an we calculate time in microsecond as per our model dimension $55 \mathrm{~mm}$ is the distance between two IR sensors of Left pair and Right side pair both distance is same. Calculate the speed in between left IR sensors pair or right pair of IR sensors ref figure 1 .

When Bothe side condition there is fraction of second of delay between left entry or right entry point who cut the IR sensors first light start that side light in full luminance.

Table 2-is shows the testing result on that basis we can say system hardware is working as per required

\begin{tabular}{|c|c|c|c|}
\hline $\begin{array}{l}\text { Device } \\
\text { Name }\end{array}$ & $\begin{array}{l}\text { Input } \\
\text { Data }\end{array}$ & $\begin{array}{l}\text { Verified } \\
\text { Results }\end{array}$ & Remarks \\
\hline $\begin{array}{l}\text { Arduino } \\
\text { Board } \\
\text { testing }\end{array}$ & $\begin{array}{l}\text { Digital } \\
\text { Signal }\end{array}$ & $\begin{array}{l}\text { Switching of } \\
\text { LEDs at } \\
\text { different } \\
\text { intervals }\end{array}$ & $\begin{array}{l}\text { Hardware } \\
\text { is } \\
\text { accurate }\end{array}$ \\
\hline $\begin{array}{l}\text { Light } \\
\text { Dependent } \\
\text { Resistor } \\
\text { testing }\end{array}$ & $\begin{array}{l}\text { Outside } \\
\text { light } \\
\text { intensity } \\
\text { values }\end{array}$ & $\begin{array}{l}\text { Dim/High } \\
\text { LEDs glows } \\
\text { according to } \\
\text { light intensity } \\
\text { and noted on } \\
\text { the Serial } \\
\text { monitor }\end{array}$ & $\begin{array}{l}\text { Hardware } \\
\text { is } \\
\text { accurate }\end{array}$ \\
\hline $\begin{array}{l}\text { IR } \\
\text { Obstacle } \\
\text { Senor } \\
\text { testing }\end{array}$ & $\begin{array}{l}\text { Sense } \\
\text { Motion }\end{array}$ & $\begin{array}{l}\text { High LEDs } \\
\text { glows whenever } \\
\text { it detects } \\
\text { motion }\end{array}$ & $\begin{array}{l}\text { Hardware } \\
\text { is } \\
\text { accurate }\end{array}$ \\
\hline
\end{tabular}

\subsection{System Software}

Arduino is an open-source hardware and software. user can designs and manufactures single-board microcontrollers and microcontroller kits for building digital devices. The opensource Arduino Software (IDE) wirte a code as per user design system it makes it easy to write code and upload it to the board. And This software can be used with any Arduino board.

\section{Algorithmic Step}




\section{International Journal of Innovations in Engineering and Science, www.ijies.net}

\section{8 .0

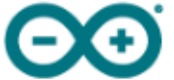 ARDUINO \\ $+0 \times-$ \\ Genuino \\ AN OPEN PROJECT WRITTEN, DEBUGGED, AND SUPPORTED BY ARDUINO.CC AND \\ THE ARDUINO COMMUNITY WORLOWIDE \\ LEARN MORE ABOUT THE CONTRIBUTORS OF ARDUINO.ce on arduino.cc/credits

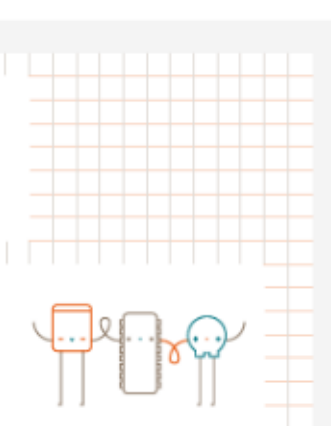

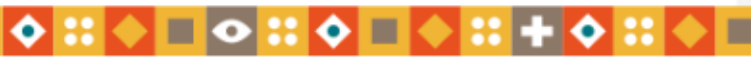

\section{Algorithmic Step}

1. Start

2. Initialize ATMEGA 328 microcontroller and all related peripheral by power ON.

3. Get the time from RTC real time clock module.

4. If there is time between 6 a.m. to 6 p.m. keep street light off.

5. If there is time between 6 p.m. to 6 a.m., turn ON street light in dimmed condition, also if LDR sensor sense darkness even if the time is in between 6 a.m. to 6 p.m. streetlights are turn $\mathrm{ON}$ in dimmed condition.

6. If there is light on and any first IR sensors pair from both sided has detected vehicle, it immediately counts time and wait for the next IR sensor triggered, now this time is defining the speed of vehicle.

7. As next IR sensor pair get triggered, first street light will be ON with its full brightness, now second light will get brighter exactly with same timing that two IR sensor has detected and it will go on brightening up to fourth street light

8. Send all data to serial monitor so that user can refer that information.

9. Stop.

\section{IV- DISCUSSION}

As our proposed system The project is designed to detect vehicle movement on highways to switch ON only a block of street lights before of vehicles and to switch dim the behind lights to save energy. Now a days during night all the lights $\mathrm{ON}$ in highway, but lots of energy is wasted when there is no vehicle movement.

\section{V- CONCLUSION}

After making the literature survey we have proposed the effective Low Cost Automation (LCA) system. We have tried to implement a model according to it and our system found very essential in saving the electricity that could be waste during conventional operating of street light in the city. This system properly shows the ON-OFF situation of street lights unattended as well as it can able to predict the speed of the vehicle and time and the direction at which the street light glows with full luminance.

In future, there are few scope, we can use LASER sensors by replacing IR sensors for wide path (just like Expresshighway) or flyover bridge. If improve our system, it can send vehicle/object Predicted speed to traffic camera to achieve more accuracy. In criminal case police (Check Post) can identify that check post vehicle is pass or not by using counting system.

\section{REFERENCES}

[1] IEEE conference 2017, Ravi kishorekodali an Subbachary Yerroju, The Energy efficient smart street light ,Department of Electronics and Communication Engineering, National Institute of Technology, Warangal.

[2] C.Bhuvaneshwari, R.Rajeswari, C.Kalaiarasan, Analysis of Solar energy based street light with auto tracking system, International Journal of Advanced Research in Electrical, Electronics and Instrumentation Engineering, Vol 2, Issue 7, July 2013.

[3] S. Suganya, R. Sinduja,T.Sowmiya\&S.Senthilkumar, Street light glow on detecting vehicle movement using sensor. International Journal of Engineering Research and General Science, Volume 4, Issue 2, March-April, 2016

[4] W. Yue; S. Changhong; Z. Xianghong; Y. Wei; "Design of new intelligent street light control system, " 8 th IEEE international Conferences on Control and Automation (ICCA), (2010), Page(s): 1423 - 1427

[5] M.Abhishek, Syedajram shah, K.Chetan, K. Arun Kumar, Design and implementation of traffic flow based street light control system with effective utilization of solar energy, International journal of Science Engineering and Advance Technology, IJSEAT, Vol 3, Issue 9, September -2015

[6] Padmadevi, S., and K. SanthaSheela. "Survey on street lighting system based on vehicle movements." Int. J. Innov.Res. Sci., Eng., Tech 3, no. 2 (2012).

[7] Steve Chadwick, "Street Light Monitoring - a Practical Solution magazine" November/December 2002.

[8] “Wireless internet lighting control system”,Budike, E.S. Lothar (Power web Technologies), US patent 7,167,777,Jan 23, 2007.

[9] http://www.hobbytronics.co.uk/arduino-uno-r3.

[10] Solar LED street light system with Automatic Scheme2017, Omveer Singh, IEEE SR.Member, Electrical Engineering Department, Greater Buddha 
Vol. 6, No. 10, 2021, PP. 125 -129

International Journal of Innovations in Engineering and Science, www.ijies.net

University,Tushar Singh Sisodia Electrical Department, Greater Noida.

[11] A smart street light intensity optimizer, IEEE Conference/2017, Bilam Roy and Jayita Datta, Department of Applied Electronics and Instrumentation Engineering, Guru Nanak Institute of Technology, Kolkata, W.B., India.

[12] Internet of Things Based Intelligence Street Lighting System for Smart city, IJIRSET, May 2016, Parkash, Prabhu V, Dandu Rajendra

[13] Automatic Street Light Control System using Wireless Sensor Networks, IEEE-2017. Dhiraj Sunehra, SMIEEE,JNTU college of Engineering, Department of Electronics and Communication Engineering, Telangana, India. 